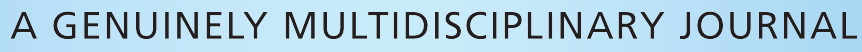 CHEMPLUSCHEM
}

CENTERING ON CHEMISTRY

\section{Accepted Article}

Title: Gold Nanoparticles Supported on Imidazole Modified Bentonite: Environmentally Benign Heterogeneous Catalyst for A3 Synthesis of Propargylamines in Water

Authors: Mohammad Gholinejad, Reza Bonyasi, Carmen Najera, Fariba Saadati, Maedeh Bahrami, and Neda Dasvarz

This manuscript has been accepted after peer review and appears as an Accepted Article online prior to editing, proofing, and formal publication of the final Version of Record (VoR). This work is currently citable by using the Digital Object Identifier (DOI) given below. The VoR will be published online in Early View as soon as possible and may be different to this Accepted Article as a result of editing. Readers should obtain the VoR from the journal website shown below when it is published to ensure accuracy of information. The authors are responsible for the content of this Accepted Article.

To be cited as: ChemPlusChem 10.1002/cplu.201800162

Link to VoR: http://dx.doi.org/10.1002/cplu.201800162

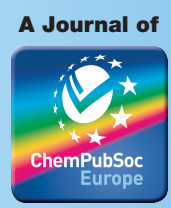




\title{
Gold Nanoparticles Supported on Imidazole Modified Bentonite: Environmentally Benign Heterogeneous Catalyst for A3 Synthesis of Propargylamines in Water
}

\author{
Mohammad Gholinejad, ${ }^{[\mathrm{[a,b]}}$ Reza Bonyasi, ${ }^{[\mathrm{c}]}$ Carmen Najera, ${ }^{*[\mathrm{~d}]}$ Fariba Saadati,${ }^{[\mathrm{c}]}$ Maedeh Bahrami, ${ }^{[\mathrm{a}]}$ \\ Neda Dasvarz ${ }^{[a]}$
}

\begin{abstract}
Gold nanoparticles supported on imidazole modified bentonite, Bent@Im@Au NPs, has been developed for the first time as an effective heterogeneous catalyst for the synthesis of propargylamines under mild reaction conditions in water with using $0.07 \mathrm{~mol} \%$ of Au. Various techniques such as X-ray diffraction, high resolution transmission electron microscopy, Fourier-transform infrared spectroscopy and element mapping by scanning electron microscopy were used to determine the physicochemical properties of the catalysts. The new gold catalyst was found to be highly active towards achieving the high to excellent yield of the A3 coupling products via the reactions of various electron withdrawing as well as electron donating aldehydes with different amines and alkynes. The catalysts can be easily recovered and reused without a significant loss of activity and the reused catalyst was characterized.
\end{abstract}

\section{Introduction}

Propargylamines are important units in biologically active intermediates in the production of pharmaceuticals and natural products. $^{[1]}$ For example propargylamines moieties have applications in the synthesis of anti-Alzheimer, anti-Parkinson, and anti-depressant drugs. ${ }^{[2]}$ Traditional methods for the synthesis of propargylamines include reaction of stoichiometric amounts of lithium or magnesium acetylides with imines ${ }^{[3]}$ and reaction of only few commercially available propargyl halides with amines. ${ }^{[4]}$ However, these methods require highly dry solvents, inert atmosphere and the use of stoichiometric amounts of organometallic reagents which inhibit the application of these methods in large scale operations. ${ }^{[5]}$

In recent years, multicomponent reactions (MCRs) receive increasing attention since they provide easy and rapid access to large group of organic compounds with diverse substitution patterns. ${ }^{[6]}$ One of the best examples of MCRs which reduce

[a] Mohammad Gholinejad, Maedeh Bahrami

Department of Chemistry, Institute for Advanced Studies in Basic

Sciences (IASBS), P. O. Box 45195-1159, Gavazang, Zanjan

45137-6731, Iran

E-mail: gholinejad@iasbs.ac.ir

[b] Mohammad Gholinejad

Research Center for Basic Sciences \& Modern Technologies (RBST), Institute for Advanced Studies in Basic Sciences (IASBS), Zanjan 45137-66731, Iran

[c] Reza Bonyasi, Fariba Saadati

Department of Chemistry, Faculty of Science, University of Zanjan,

P. O. Box 45195-313, Zanjan, Iran

[d] Carmen Najera

Departamento de Química Orgánica and Centro de Innovación en

Química Avanzada (ORFEO-CINQA). Universidad de Alicante,

Apdo. 99, E-03080-Alicante, Spain

Email: cnajera@ua.es

Supporting information for this article is given via a link at the end of the document. waste and increase safety, is the catalytic coupling reaction of aldehydes, amines and terminal alkynes (A3 coupling) via $\mathrm{C}-\mathrm{H}$ activation of alkynes for the synthesis of propargylamines. ${ }^{[7]}$ Recently, many transition-metal catalysts such as $\mathrm{Ir}^{[8]} \mathrm{Ag},{ }^{\left[{ }^{[0]}\right.}$ $\mathrm{Cu},{ }^{[7]}$ a $\mathrm{Cu}-\mathrm{Ru}$ bimetallic system, ${ }^{[9]} \mathrm{Fe},{ }^{[11]} \mathrm{Zn},{ }^{[12]}$ and $\mathrm{In}{ }^{[13]}$ have been suggested as new catalysts for the preparation of propargylamines. Because of the well-recognized catalytic properties of gold(I) and (III) in recent years, gold based catalysts are recognized as efficient catalysts in various organic transformations. ${ }^{14}$ One of the most interesting studied applications of gold catalysts was in A3 coupling reaction via gold activation of the sp C-H bond. ${ }^{15}$ Along this line, in recent years different various gold catalysts have been introduced for A3 coupling reaction under homogeneous conditions. ${ }^{[16]}$ In spite of the high price of gold and problem of recycling of homogeneous catalysts, less examples of heterogeneous recyclable gold catalysts have been described for A3 coupling reaction. ${ }^{[17,18]}$

Selection of support and suitable functionalization are important factors for design of efficient heterogeneous catalysts. Different organic and inorganic materials such as polymers, magnetic and silica based compound were used for stabilization of metal nanoparticles. Clay minerals having different properties such as mechanical and thermal stability, high surface area and ion exchange capacity, and economical price are promising supports for the preparation heterogeneous catalysts. ${ }^{[19]}$ Among the different clay minerals, bentonite is a naturally occurring materials which is formed by volcanic ash. Bentonite comprises mainly of crystalline clay minerals belonging to the smectite group, which are hydrous aluminum silicates containing $\mathrm{Fe}, \mathrm{Mg}$, $\mathrm{Na}$, and $\mathrm{Ca}$ elements. ${ }^{[20]}$ Recently, surface modifications of clay with new ligands have received considerable attention because it allows the formation of new organo-clays with desired properties. ${ }^{[21]}$ Along this line bentonite-supported catalysts have been applied to several types of organic reactions. ${ }^{[22]}$ However to date very limited bentonite-supported gold catalysts have been essayed in organic reactions ${ }^{[23]}$ and there is no report dealing with bentonite-supported gold catalyst applied in A3 coupling reaction.

Herein, we report for the first time a novel gold nanoparticle supported on poly imidazole modified bentonite is an efficient, simple and sustainable catalyst in the three-component coupling reaction of aldehydes, amines and terminal alkynes at low catalyst loading and under mild reaction conditions in water. 


\section{Results and Discussion}

For the preparation of bentonite-supported gold nanoparticles (NPs), bentonite was allowed to react with acryloyl chloride in dry THF. The successful attachment of acryloyl was pursued through FTIR spectroscopy showing the carbonyl stretching bond at $1735 \mathrm{~cm}^{-1}$ (Figure 1 in supporting information). In the next step, the resulting solid $\mathbf{1}$ was treated with vinylimidazole in the presence of benzoyl peroxide as initiator. Finally to the bentonite modified polyimidazole 2 was added $\mathrm{NaAuCl}_{4} \cdot 2 \mathrm{H}_{2} \mathrm{O}$ and $\mathrm{NaBH}_{4}$ in water. The obtained new gold composite 3 is referred as Bent@Im@Au NPs through the text. Content of nitrogen and gold have been determined by elemental analysis and atomic absorption spectroscopy to be 1.1 and $0.02 \mathrm{mmol} / \mathrm{g}$, respectively.

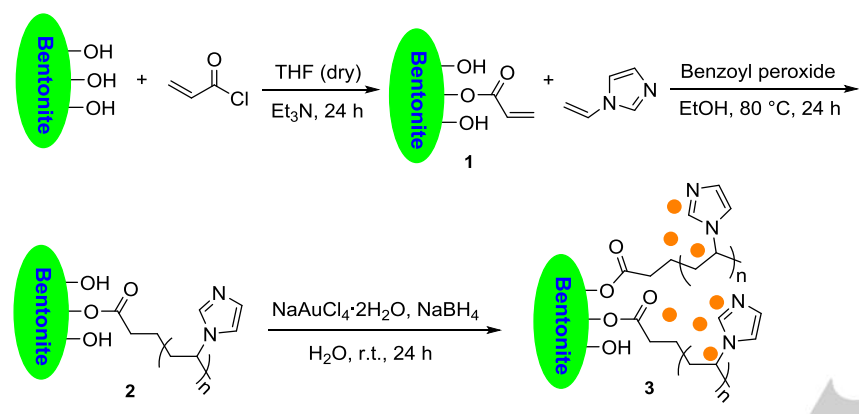

Scheme 1. Preparation of Bent@Im@Au NPs.

Field emission scanning electron microscopy (FESEM) images of Bent@Im@Au showed presence of gold nanoparticles (bright points) stabilized on sheets of bentonite (Figure 1).

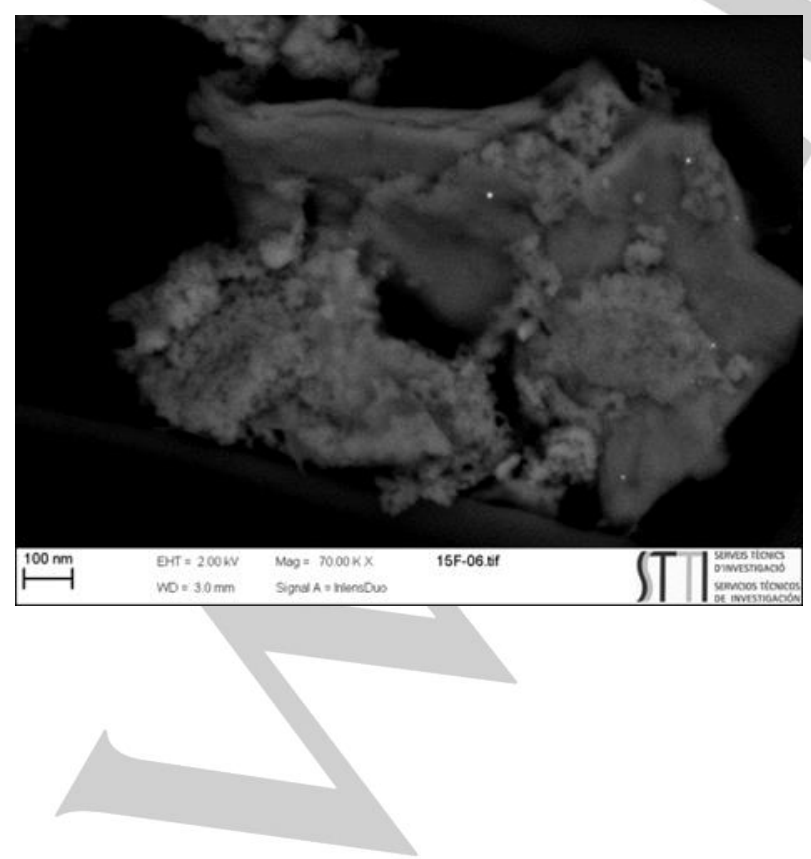

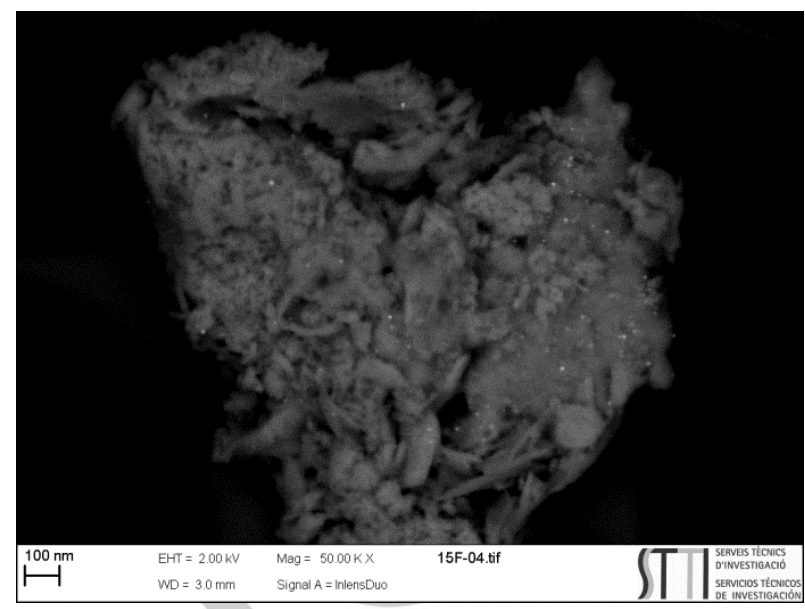

Figure 1. FESEM images of Bent@Im@Au.

EDX-map analysis of Bent@Im@Au showed the presence of highly uniform and dispersed $\mathrm{Au}$ as well as $\mathrm{N}$ and $\mathrm{C}$ species in the structure (Figure 2 in supporting information). Also, total map image of the Bent@Im@Au showed that the Au nanoparticles are located very uniformly without any agglomeration (Figure 3 in supporting information). In addition, the presence of different elements such as $\mathrm{C}, \mathrm{N}, \mathrm{O}, \mathrm{Mg}, \mathrm{Ca}, \mathrm{Na}, \mathrm{Al}, \mathrm{Si}$, and $\mathrm{Au}$ was proved in the structure (Figure 4, supporting information). HighResolution Transmission Electron Microscopy (HRTEM) images from Bent@Im@Au showed small and uniform Au NPs in around 1-2 nm size which are stabilized in the solid surface (Figure. 2).

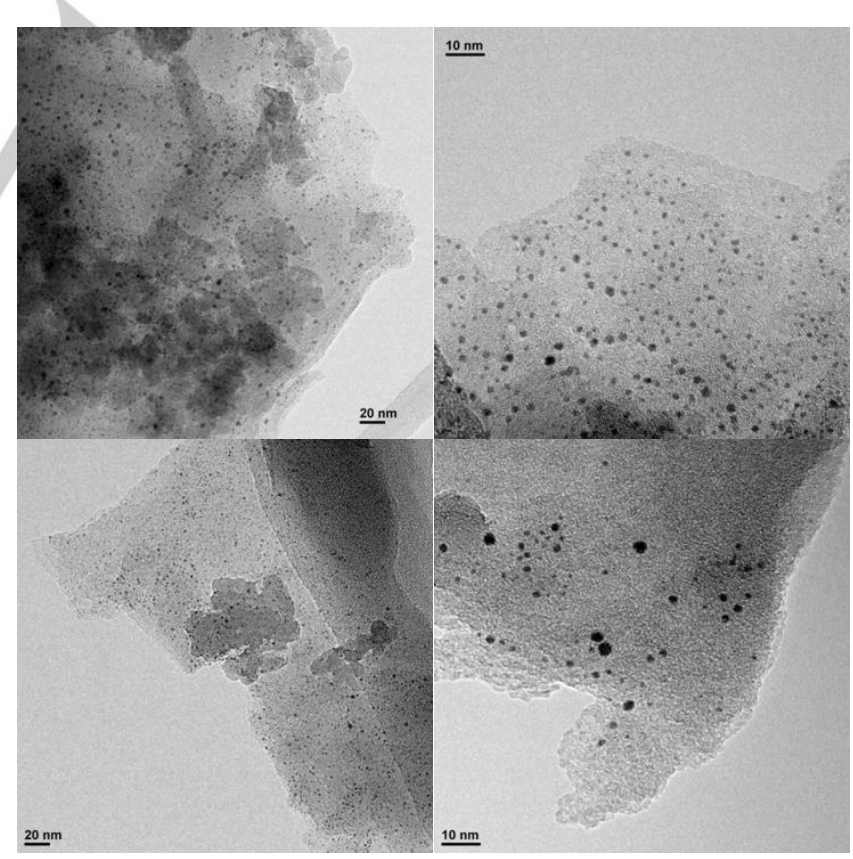

Figure 2. TEM images of Bent@Im@Au in different magnification 
X-ray powder diffraction (XRD) of Bent@Im@Au was also studied (Figure 5 in the Supporting Information). However, due to low loading weight of $\mathrm{Au}$ on the support and also the overlap of bentonite peaks ${ }^{22 z, 24}$ with Au NPs, this diffractogram did not show any significant peaks for Au NPs. Therefore we studied Xray photoelectron spectroscopy (XPS) of Bent@Im@Au for Na, $\mathrm{Ca}, \mathrm{Al}, \mathrm{N}, \mathrm{Si}$, and Au elements. XPS spectrum in $\mathrm{Na} 1 \mathrm{~s}$ confirms the presence of $\mathrm{Na}(\mathrm{I})$ in the structure of bentonite by showing a peak at $1072.5 \mathrm{eV}$ (Figure 3a). ${ }^{[25]}$ XPS study in the Ca $2 p$ region showed a doublet peak centered at 347.1 and $351.1 \mathrm{eV}$ related to the $\mathrm{Ca}(\mathrm{II})$ in the solid structure (Figure $3 \mathrm{~b}) .{ }^{[26]}$ The core-level photoelectron spectrum of $\mathrm{Al} 2 \mathrm{p}$ between $72-76 \mathrm{eV}$ was deconvoluted into two main peaks at 74.2 and $74.70 \mathrm{eV}$, which are related to $\mathrm{Al}(\mathrm{III})$ in $\mathrm{Al}-\mathrm{OH}$ and $\mathrm{Al}_{2} \mathrm{O}_{3}$ forms (Figure $3 \mathrm{c}$ ). ${ }^{[27]}$ The binding energy (BE) value of $\mathrm{Si} 2 \mathrm{p}$ in silanol $(\mathrm{Si}-\mathrm{OH})$ and silicone oxygen (Si-O) bond appeared at 102.4 and $103.1 \mathrm{eV}$, respectively (Figure $3 d$ ). ${ }^{[27 a]}$ In order to confirm the presence of the imidazole group, XPS analysis for N1s region was studied indicating the presence of two peaks at 398.9 and $401.05 \mathrm{eV}$ which can be attributed to the $\mathrm{C}=\mathrm{N}$ and $\mathrm{C}-\mathrm{N}$ bonds of the imidazole (Figure 3e). ${ }^{[28]}$ Finally the XPS spectrum in the Au $4 \mathrm{f}$ region showed two intense doublets at 83.4 and $87.2 \mathrm{eV}$ corresponding to $\mathrm{Au}(0)$ and 85.1 and $88.6 \mathrm{eV}$ related to $\mathrm{Au}(\mathrm{I})$ species (Figure $3 \mathrm{f}$ ). These results confirm that during the final catalyst preparation step most of ionic Au was successfully reduced to metallic form.

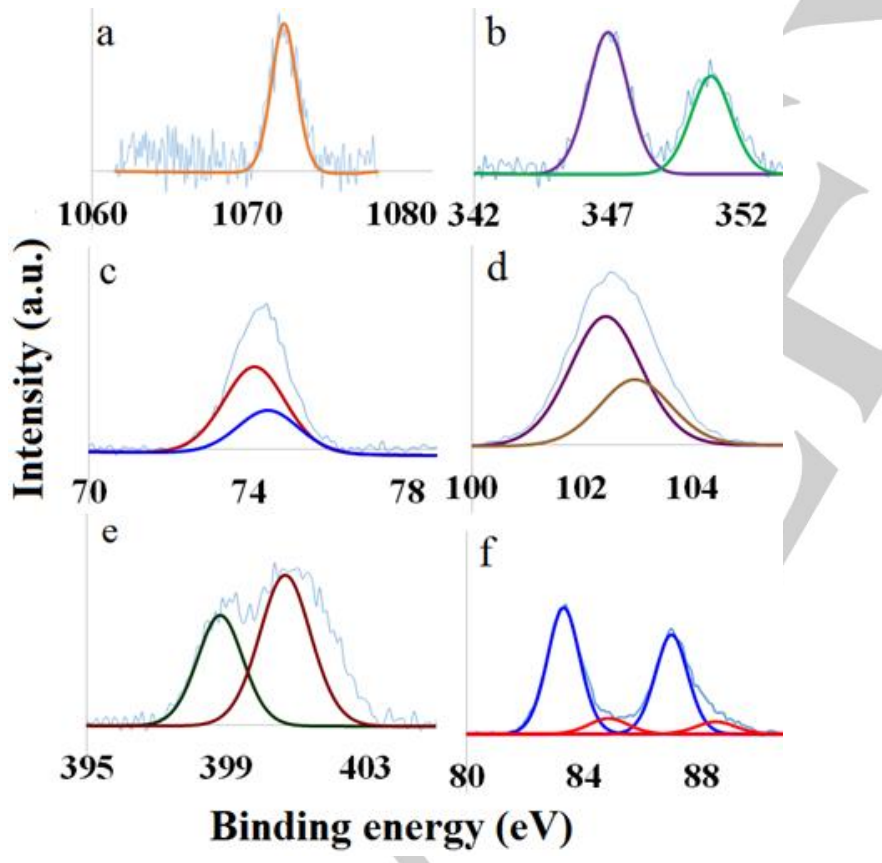

Figure 3. XPS spectrum of Bent@Im@Au NPs (3) in a) Na1s, b) Ca 2p, c) Al2p, d) Si2p, e) N1s and Au $4 f$ regions.

The catalytic activity of Bent@Im@Au NPs was examined in the three-component A3 reaction of amines, aldehydes and alkynes. For this purpose, initially reaction of benzaldehyde, piperidine and phenylacetylene was selected as model reaction to study the effect of different factors such as solvent, reaction temperature and catalyst amount (Table 1). Using $0.07 \mathrm{~mol} \%$ catalyst loading at $50{ }^{\circ} \mathrm{C}$ in different solvents such as $\mathrm{CH}_{3} \mathrm{CN}$, $\mathrm{EtOH}, \mathrm{THF}, \mathrm{DMF}$, toluene, and $\mathrm{H}_{2} \mathrm{O}$ gave high to quantitative yields for the reaction (Table 1, entries 1-6). For further optimization studies we selected water as the best green solvent and performed reaction using 0.07 and $0.05 \mathrm{~mol} \%$ of catalyst 3 . Under these reaction conditions, 100 and $90 \%$ yield were obtained respectively (Table 1 , entries 7 and 8 ). Therefore, we selected $0.07 \mathrm{~mol} \%$ catalyst as the optimum amount. Also, using $0.07 \mathrm{~mol} \%$ of catalyst and lowering the reaction time and temperature, gave lower yields for the reaction (Table 1, entries 9 and 10). It should be noted that reaction in the absance of gold using bentonite and imidazole functinalized bentonite (2) failed to proceed (Table 1, entries 11 and 12). Also reactions using bentonite supported $\mathrm{Au}$ before addition of $\mathrm{NaBH}_{4}$ and bentonite supported $\mathrm{Au}$ reduced with hydrazine gave low yield (Table 1, entries 13 and 14 ).

Table 1. Optimization of the reaction conditions for the reaction of benzaldehyde, piperidine and phenylacetylene catalyzed by Bent@Im@Au ${ }^{[a]}$

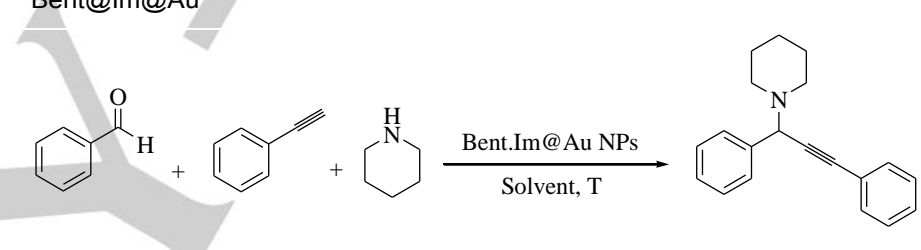

\begin{tabular}{llll}
\hline Entry & Catalyst (mol\%) & Solvent & Yield $(\%)^{\mathrm{b}}$ \\
\hline 1 & 0.1 & $\mathrm{CH}_{3} \mathrm{CN}$ & 100 \\
2 & 0.1 & $\mathrm{EtOH}$ & 95 \\
3 & 0.1 & $\mathrm{THF}$ & 84 \\
4 & 0.1 & $\mathrm{DMF}$ & 100 \\
5 & 0.1 & $\mathrm{Toluene}$ & 100 \\
6 & 0.1 & $\mathrm{H}_{2} \mathrm{O}$ & 100 \\
7 & 0.07 & $\mathrm{H}_{2} \mathrm{O}$ & 100 \\
8 & 0.05 & $\mathrm{H}_{2} \mathrm{O}$ & 90 \\
9 & 0.07 & $\mathrm{H}_{2} \mathrm{O}$ & $61^{\mathrm{c}}$ \\
10 & 0.07 & $\mathrm{H}_{2} \mathrm{O}$ & $52^{\mathrm{d}}$ \\
11 & - & $\mathrm{H}_{2} \mathrm{O}$ & $0^{\mathrm{e}}$ \\
12 & - & $\mathrm{H}_{2} \mathrm{O}$ & $0^{\mathrm{f}}$ \\
13 & 0.07 & $\mathrm{H}_{2} \mathrm{O}$ & $19^{\mathrm{g}}$ \\
14 & 0.07 & $\mathrm{H}_{2} \mathrm{O}$ & $26^{\mathrm{h}}$ \\
\hline & & & \\
\hline
\end{tabular}

[a]Reaction conditions: benzaldehyde $(1 \mathrm{mmol})$, piperidine $(1.5 \mathrm{mmol})$, phenylacetylene $(1.5 \mathrm{mmol})$ and solvent $(2 \mathrm{~mL})$ for $1 \mathrm{~d}$.

[b] Isolated crude yields determined by $1 \mathrm{H}$ NMR. 
[c] Reaction performed during $12 \mathrm{~h}$.

[d] Reaction performed at $25^{\circ} \mathrm{C}$

[e] Reaction using $35 \mathrm{mg}$ bentonite as catalyst

[f] Reaction using $35 \mathrm{mg} \mathrm{(3)}$ as catalyst

[g] Reaction using bentonite supported $\mathrm{Au}(0.07 \mathrm{~mol} \%)$ without reducing agent

[h] Reaction using bentonite supported $\mathrm{Au}(0.07 \mathrm{~mol} \%)$ with hydrazine as reducing agent.

Having the optimized reaction conditions in hand, reactions of various aldehydes with secondary amines and alkynes were studied (Table 2). The obtained results indicated that the reactions of different aromatic aldehydes containing electrondonating and -releasing groups such as $\mathrm{Cl}, \mathrm{Br}$ and $\mathrm{Me}$ as well as 1-naphtaldehyde and biphenyl-4-carboxaldehyde with piperidine and phenylacetylene proceed effectively and the corresponding propargylamines were obtained in high to excellent isolated yields (Table 2, entries 1-10). Reaction of 3thiophenecarbaldehyde as heterocyclic aldehyde took place well without poisoning or deactivation of the catalyst (Table 2, entry 11). Furthermore, reaction of aromatic and aliphatic aldehydes with other secondary amines such as morpholine, pyrrolidine and dimethylamine occurred efficiently affording the corresponding propargylamines in high to excellent yields (Table 2 , entries 12-19). It should be noted reaction of pentanal and heptanal as aliphatic aldehydes with morpholine or piperidine and phenylacetylene performed effectively and desired products obtained in 81 and $89 \%$ isolated yields respectively (Table 2, entries 20 and 21). Furthermore reaction of 1-octyne as aliphatic alkyne with benzaldehyde and piperidine proceed well and the corresponding product was obtained in $85 \%$ isolated yields (Table 2, entry 22).

Table 2. The reactions of different aldehydes, amines and alkynes in the presence of Bent@Im@Au as catalyst. ${ }^{[\mathrm{a}]}$

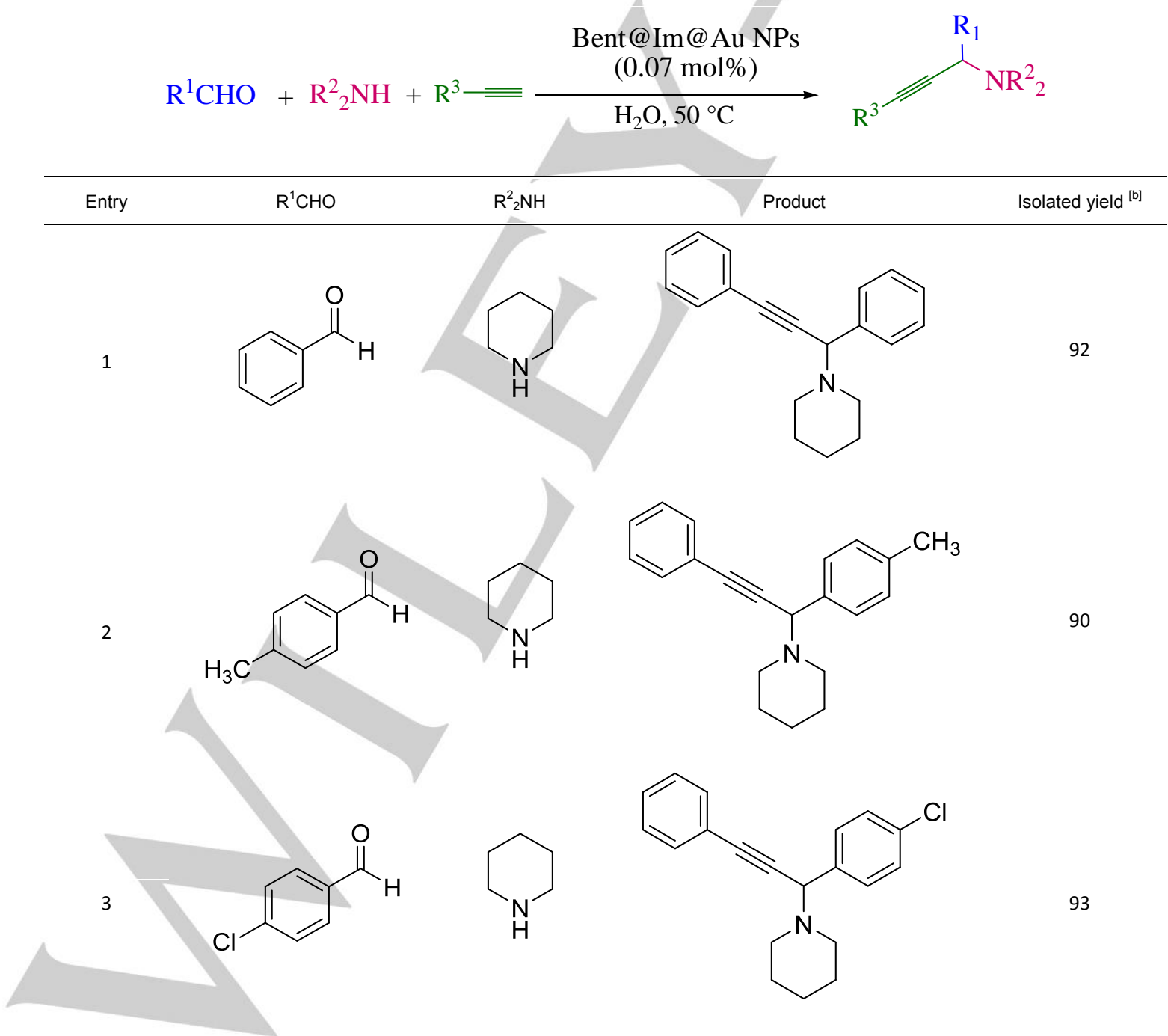


4<smiles>O=Cc1ccc(Br)cc1</smiles>

5<smiles>Cc1cccc(C=O)c1</smiles><smiles>O=Cc1ccccc1Cl</smiles>

7<smiles>O=Cc1ccc(Cl)cc1Cl</smiles><smiles>C1CCNCC1</smiles><smiles>C1CCNCC1</smiles><smiles>c1ccccc1</smiles><smiles>C#CC(c1cccc(C)c1)N1CCCCC1</smiles><smiles>Clc1ccccc1C(C#Cc1ccccc1)N1CCCCC1</smiles>

90

89 $84^{[c]}$ 
10<smiles>O=Cc1ccc(-c2ccccc2)cc1</smiles>

11<smiles>O=Cc1ccsc1</smiles>

12<smiles>O=Cc1ccccc1</smiles>

13<smiles>O=Cc1ccccc1Cl</smiles>

14<smiles>O=Cc1ccccc1</smiles><smiles>C1CCNCC1</smiles><smiles>C1COCCN1</smiles><smiles>C(#CC(c1ccccc1)N1CCOCC1)c1ccccc1</smiles><smiles>C1COCCN1</smiles><smiles>Clc1ccccc1C(C#Cc1ccccc1)N1CCOCC1</smiles><smiles>C(#CC(c1ccccc1)N1CCCC1)c1ccccc1</smiles><smiles>c1ccccc1</smiles><smiles>C(#CC(c1ccc(-c2ccccc2)cc1)N1CCCCC1)c1ccccc1</smiles> 
16<smiles>O=Cc1ccc(Cl)cc1</smiles>

17<smiles>O=Cc1ccc(Br)cc1</smiles><smiles>O=Cc1ccccc1Cl</smiles>

19<smiles>O=Cc1ccccc1</smiles>

20<smiles>C1CCNC1</smiles><smiles>C1CCNC1</smiles><smiles>C1CCNC1</smiles><smiles>Clc1ccc(C(C#Cc2ccccc2)N2CCCC2)cc1</smiles><smiles>NC(C#Cc1ccccc1)c1ccc(Br)cc1</smiles><smiles>C1CCNC1</smiles><smiles>Clc1ccccc1C(C#Cc1ccccc1)N1CCOCC1</smiles>

$83^{[\mathrm{c}]}$

87

$82^{\text {[c] }}$<smiles>CCCCC=O</smiles>

21<smiles>CCCCCCC=O</smiles><smiles>CCCCCCC(C#Cc1ccccc1)N1CCCCC1</smiles><smiles>C1COCCN1</smiles><smiles>c1ccccc1</smiles><smiles>C#CC</smiles><smiles>CN1CCCCC1</smiles>

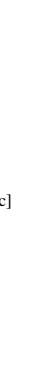


22<smiles>O=Cc1ccccc1</smiles><smiles>C1CCNCC1</smiles>

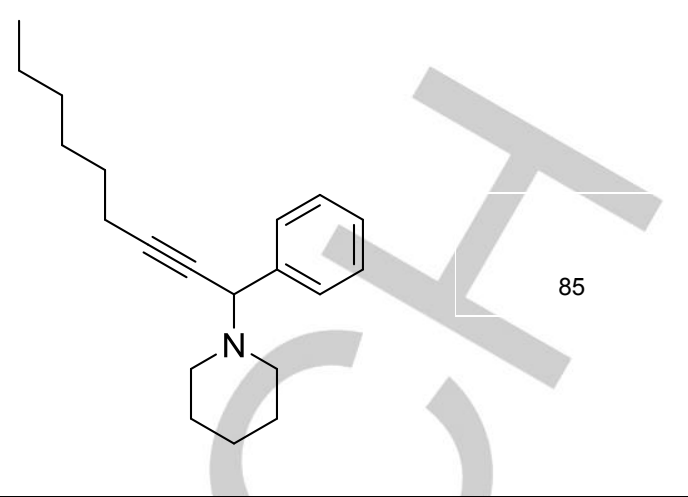

[a] Reaction conditions: aldehyde ( $1 \mathrm{mmol})$, amine $(1.5 \mathrm{mmol})$, alkyne $(1.5 \mathrm{mmol}), \mathrm{H}_{2} \mathrm{O}(2 \mathrm{~mL})$, catalyst $(35 \mathrm{mg}$, containing $0.07 \mathrm{~mol} \% \mathrm{Au})$, and during $1 \mathrm{~d}$.

[b] Isolated yields after column chromatography.

[c] Reaction timels $30 \mathrm{~h}$

Comparison catalytic activity of Bent@Im@Au catalyst with othersupported gold catalyst in A3 coupling reaction of 4methylbenzaldehyde, piperidine and phenylacetylene as a common substrate (Table 3), showed overall efficiency of the presented catalyst (Bent@Im@Au). Also, It should be noted that in compared to our previous reports regarding A3 coupling reaction, ${ }^{[7 \mathrm{~b}, 17 \mathrm{i}, 18 \mathrm{f}-\mathrm{g}]}$ novel Bent@Im@Au catalysed reactions under mild and greener reaction conditions $\left(50^{\circ} \mathrm{C}\right.$ in water). Briefly, the advantages of the catalyst are described below. 1) Bentonite was modified for the first time with poly imidazole with very simple methode; 2) Poly imidazole modified bentonite was used for the stabilization of gold NPs; 3) The new material was used for the first time as the catalyst in A3 coupling reaction; 4) In comapred to other previous Au catalysts and our reported Au or $\mathrm{Cu}$ catalysts, reactions proceed efficiently under mild reaction conditions in water.

Table 3. Comparison catalytic activity of Bent@Im@Au with other reported Au catalysts in A3 coupling reaction

\begin{tabular}{|c|c|c|c|c|}
\hline Catalyst & $\mathrm{T}\left({ }^{\circ} \mathrm{C}\right) / \mathrm{t}(\mathrm{h})$ & Solvent & $\begin{array}{c}\mathrm{Au} \\
\mathrm{mol} \%\end{array}$ & Yield \\
\hline $\mathrm{Au}_{38}\left(\mathrm{SC}_{2} \mathrm{H}_{4} \mathrm{Ph}\right)_{24}{ }^{161}$ & & Solvent-free & 0.01 & 84 \\
\hline Au@PMO-IL ${ }^{17 i}$ & $60 / 11$ & $\mathrm{CHCl}_{3}$ & 0.2 & 88 \\
\hline NAP-Mg-Au(0) $)^{17 f}$ & $100 / 24$ & Toluene & 0.04 & 81 \\
\hline MNP@PILAu ${ }^{18 a}$ & $60 / 18$ & $\mathrm{H}_{2} \mathrm{O}$ & 1 & 95 \\
\hline Au NPs ${ }^{17 n}$ & $75 / 12$ & $\mathrm{CH}_{3} \mathrm{CN}$ & 10 & 83 \\
\hline $\mathrm{Au}_{25}(\mathrm{PET})_{18}{ }^{18 \mathrm{~d}}$ & $80 / 24$ & Toluene & 0.1 & 89 \\
\hline Au@HS-MCM ${ }^{18 \mathrm{e}}$ & $80 / 24$ & $\mathrm{H}_{2} \mathrm{O}$ & 2 & 75 \\
\hline IRMOF-3-LA-Au ${ }^{18 \mathrm{~h}}$ & $80 / 7$ & 1,4-dioxane & 1.7 & 54 \\
\hline
\end{tabular}

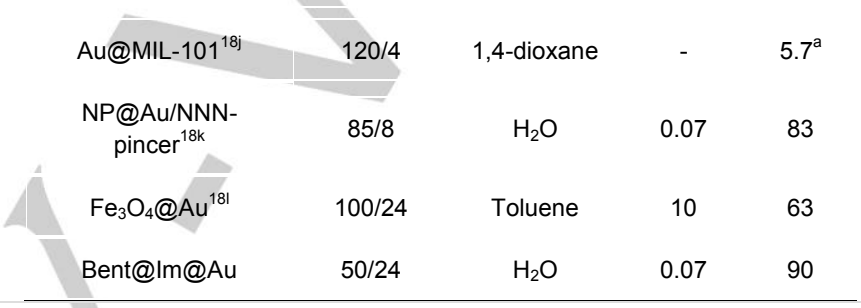

[a] $60 \mathrm{mg}$ catalyst containing $4.96 \mathrm{wt} \%$ gold

Since the recovering and reusing of heterogeneous catalysts are very important aspects for sustainable chemistry and economical stand points, we studied recycling of the catalyst in the model reaction of benzaldehyde, piperidine and phenylacetylene under optimized reaction conditions. For this purpose, in each run after $24 \mathrm{~h}$, catalyst was separated by centrifugation and after washing with ethyl acetate and drying was used in another reaction batch. Results showed this catalyst 3 was recyclable for 7 runs with small decrease in activity (Figure 4).

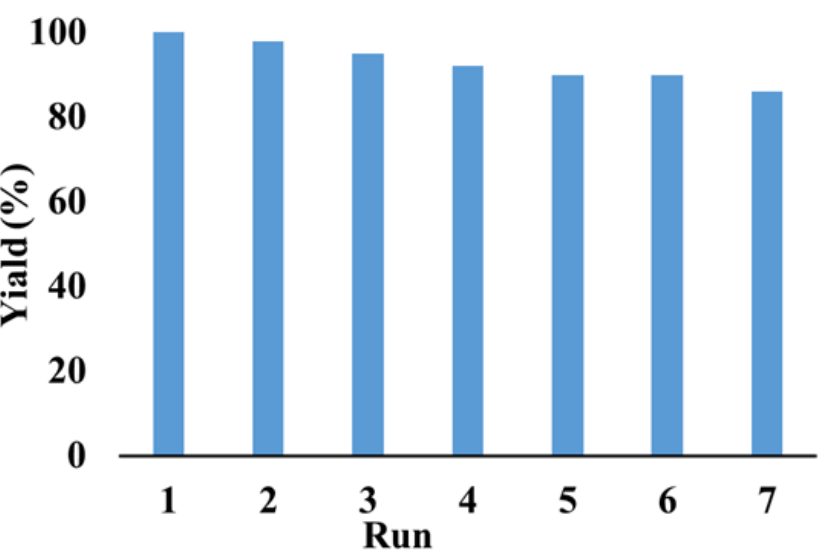

Figure 4 Recycling of the catalyst for the reaction of benzaldehyde, piperidine and phenylacetylene. 
FESEM mages of the reused catalyst after 7 runs showed very similar pattern to fresh catalyst (Figure 5). However, TEM images of reused catalyst after 7 runs showed presence of mostly uniform nanoparticles and sligtly aggrigate form. (Figure $6)$.

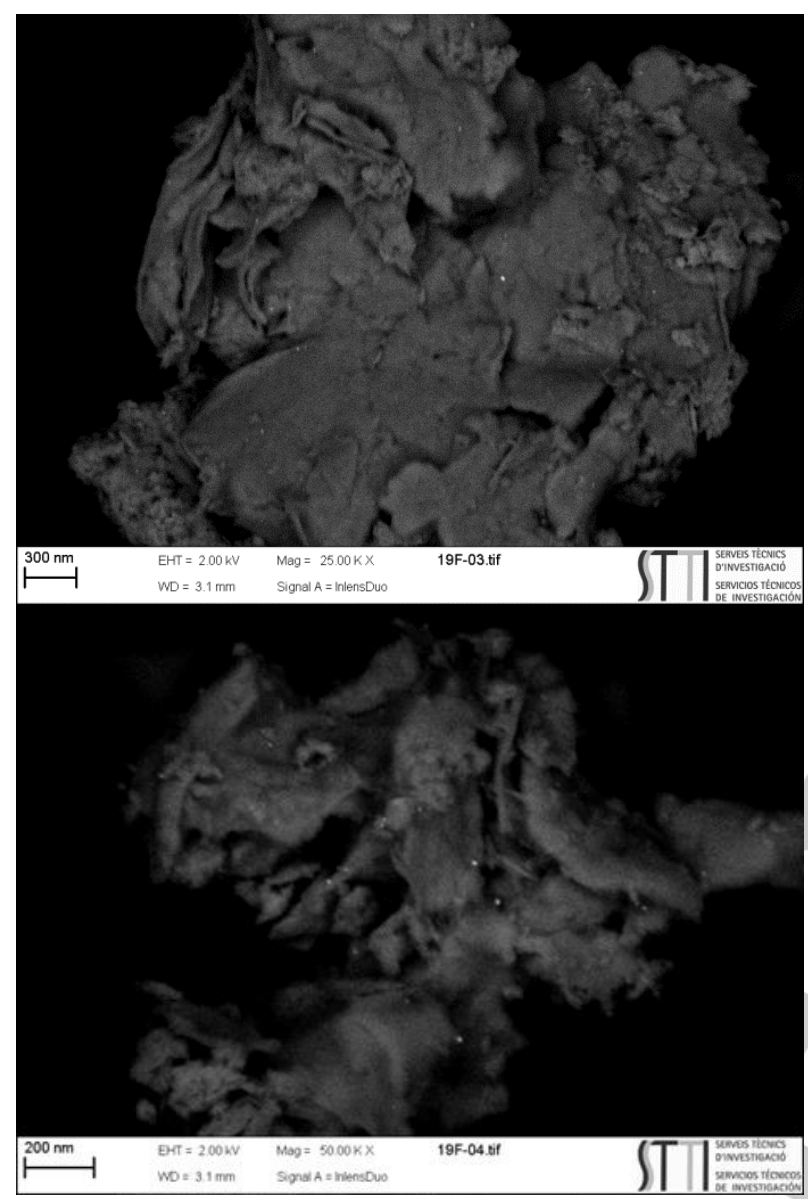

Figure 5 FESEM images of reused catalyst after 7 runs.

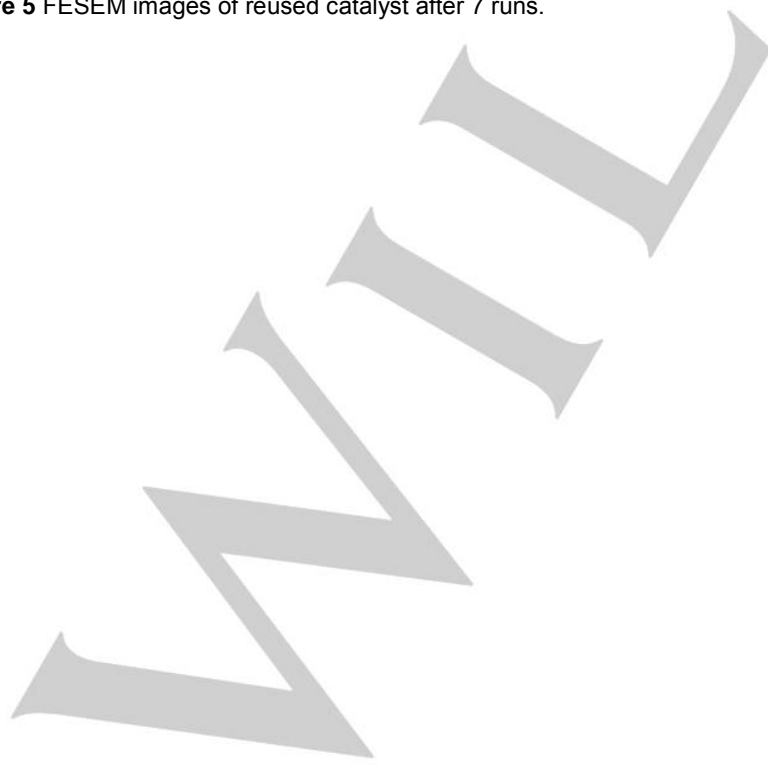

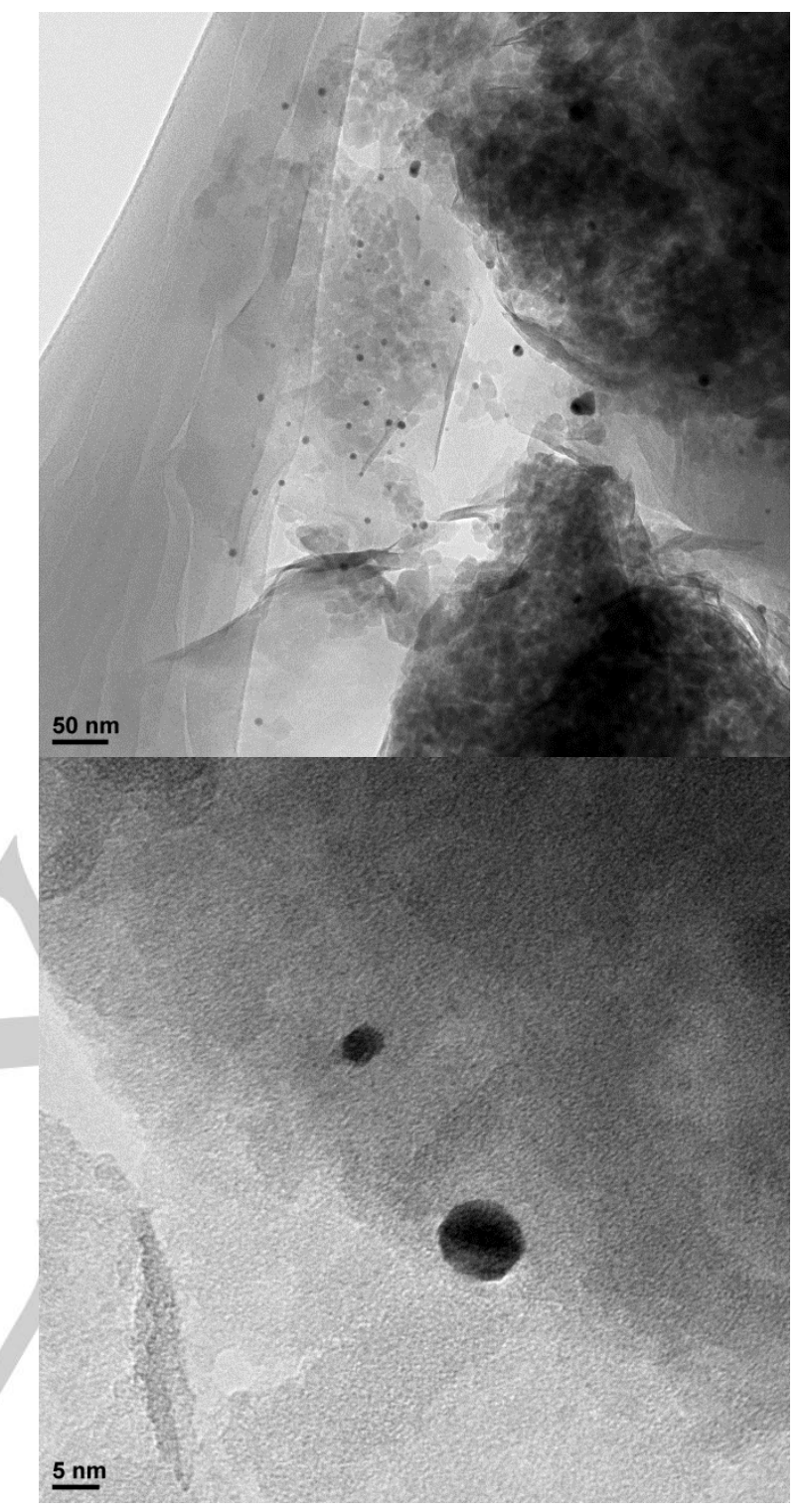

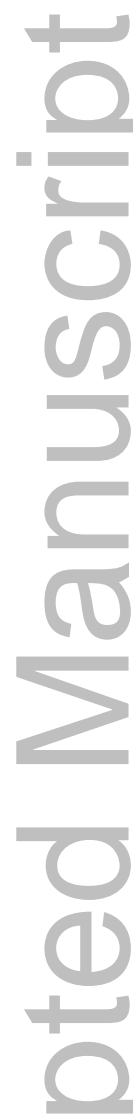

Figure 6 TEM images of reused catalyst after 7 runs

In addition, XPS analysis of the reused catalyst showed stability and the presence of imidazole group in the structure. On the other hand, the XPS spectrum in the Au $4 \mathrm{f}$ region indicates the presence of $A u(0)$ as a sole species in the reused catalyst structure, it means that during the $\mathrm{A} 3$ reaction all of the ionic $\mathrm{Au}$ species were reduced to $A u(0)$ (Figure 7). Atomic absorption spectroscopy of the reused catalyst after seven runs showed the amount of leaching of Au was $2.7 \%$. 


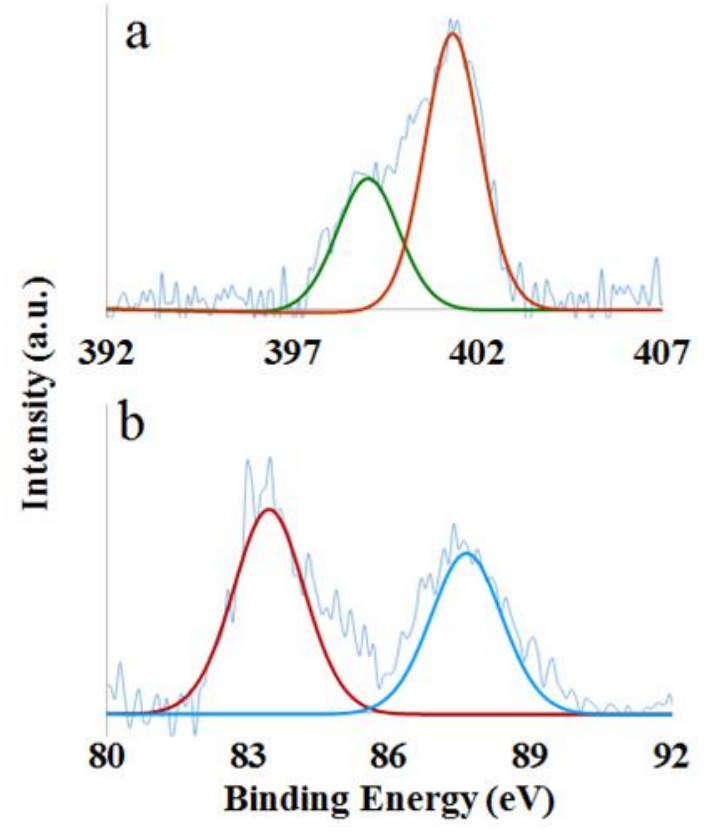

Figure 7 XPS analysis of reused catalyst after 7 runs a) N1S and b) Au $4 f$ regions.

\section{Conclusions}

The new bentonite supported Au catalyst, Bent@Im@Au, prepared by a very simple method and characterized by different techniques. The catalyst showed good activity in synthesis of propargylamines via $\mathrm{A} 3$ coupling reaction in water at $50^{\circ} \mathrm{C}$. Both aromatic and aliphatic aldehydes and alkynes were reacted effectively with different amines. Using centrifuge separation, catalyst was recovered and reused for seven consecutive runs with small decrease of activity.

\section{Experimental Section}

\section{General}

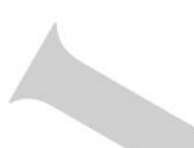

All chemicals were purchased from Sigma-Aldrich, Acros, and Merck companies and were used without further purification. All ${ }^{1} \mathrm{H}$ and ${ }^{13} \mathrm{C}$ NMR were recorded on a Bruker 400 and $250 \mathrm{MHz}$ spectrometer at 400 $\mathrm{MHz}$ and $62.5 \mathrm{MHz}$, respectively. Chemical shifts were given as $\delta$ values with reference to tetramethylsilane (TMS) as the internal standard. FT-IR spectra were recorded on a Bruker Vector 22. Transmission electron microscopy (TEM) was performed by JEOL JEM-2010 instrument. Scanning electron microscopy (SEM) was performed by Hitachi S3000N. Energy dispersive X-ray analysis (EDX) results were obtained using Carl Zeiss Sigma instrument. The content of gold in the catalyst was determined using Varian atomic absorption spectrometry. X-Ray diffraction was performed using Bruker D8-Advance.

\section{Preparation of polyimidazole functionalized bentonite (2)}

In a $25 \mathrm{~mL}$ flask, bentonite $(1 \mathrm{~g})$ was sonicated in THF $(15 \mathrm{~mL})$ for $10 \mathrm{~min}$ Then, acryloyl chloride $(10 \mathrm{mmol}, 0.8 \mathrm{~mL})$ and $\mathrm{Et}_{3} \mathrm{~N}(15 \mathrm{mmol}, 2.1 \mathrm{~mL})$ were added at $0{ }^{\circ} \mathrm{C}$ under argon atmosphere. Then the mixture was stirred for $24 \mathrm{~h}$ at room temperature and was subjected to centrifugation. The obtained isolated solid was washed with distilled water $(2 \times 15 \mathrm{~mL})$ and ethanol $(2 \times 15 \mathrm{~mL})$ and then dried in an oven at $70{ }^{\circ} \mathrm{C}$ giving product 1. For introducing the imidazole group, product $1(1 \mathrm{~g})$ was dissolved in $\mathrm{EtOH}(20 \mathrm{~mL})$ and the mixture was deoxygenated by bubbling argon for 5 min. Then, $N$-vinilimidazole $(10 \mathrm{mmol}, 0.9 \mathrm{~mL})$ and benzoyl peroxide (8 $\mathrm{mg}$ ) were added and the mixture was stirred at $80{ }^{\circ} \mathrm{C}$ for $24 \mathrm{~h}$. The resulting suspension was centrifuged and the resulting solid (2) was washed with water $(15 \mathrm{~mL})$ and ethyl acetate $(3 \times 15 \mathrm{~mL})$ and dried at 60 ${ }^{\circ} \mathrm{C}$.

Preparation of Bent@Im@Au NPs (3)

$\mathrm{NaAuCl}_{4} \cdot 2 \mathrm{H}_{2} \mathrm{O}(0.03 \mathrm{mmol}, 12 \mathrm{mg})$ was dissolved in $\mathrm{H}_{2} \mathrm{O}(1 \mathrm{~mL})$ and bentonite $(800 \mathrm{mg})$, which was previously sonicated in $\mathrm{H}_{2} \mathrm{O}(10 \mathrm{~mL})$, was added. Then, an aqueous solution of $\mathrm{NaBH}_{4}(0.3 \mathrm{mmol}, 11 \mathrm{mg}$ in $1 \mathrm{~mL}$ water) was added slowly and the mixture was stirred for $24 \mathrm{~h}$ at room temperature under argon atmosphere. The resulting solid was separated with centrifugation, and washed with water $(3 \times 10 \mathrm{~mL})$ and ethyl acetate $(3 \times 10 \mathrm{~mL})$ and finally dried at $60{ }^{\circ} \mathrm{C}$. Atomic absorption spectroscopy analysis indicated that the $\mathrm{Au}$ content $0.55 \mathrm{wt}(0.02 \mathrm{mmol} / \mathrm{g})$.

\section{General procedure for the synthesis of propargylamines}

To a $5 \mathrm{~mL}$ flask, the catalyst (35 mg, containing $0.07 \mathrm{~mol} \% \mathrm{Au}$ ), aldehyde (1 $\mathrm{mmol})$, amine $(1.5 \mathrm{mmol})$, phenylacetylene $(1.5 \mathrm{mmol})$ and $\mathrm{H}_{2} \mathrm{O}(2 \mathrm{~mL})$ were added and the mixture was stirred at $50{ }^{\circ} \mathrm{C}$ for $24 \mathrm{~h}$. After the complication of reaction, the crude products were extracted using ethyl acetate $(4 \times 5 \mathrm{~mL})$. Further purification was performed by column chromatography on silica gel using hexane and ethyl acetate as eluent All products were characterized by ${ }^{1} \mathrm{H}$ NMR and ${ }^{13} \mathrm{C}$ NMR.

\section{Acknowledgements}

The authors are grateful to Institute for Advanced Studies in Basic Sciences (IASBS) Research Council and Iran National Science Foundation (INSF-Grant number of 95844587) for support of this work. C. Nájera is also thankful for financial support to the Spanish Ministerio de Economía y Competitividad (MINECO) (projects CTQ2013-43446-P and CTQ2014-51912REDC), the Spanish Ministerio de Economía, Industria y Competitividad, Agencia Estatal de Investigación (AEI) and Fondo Europeo de Desarrollo Regional (FEDER, EU) (projects CTQ2016-76782-P and CTQ2016-81797-REDC), the Generalitat Valenciana (PROMETEOII/2014/017) and the University of Alicante.

Keywords: Bentonite • Gold• A3 coupling • Water • Heterogeneous

[1] A. P. Kozikowski, J. Med. Chem. 2000, 43, 2064-2071; b) A. Kochman, J Skolimowski, L. Gêbicka, D. Metodiewa, Pol. J. Pharmacol. 2003, 55, 389-400; c) B. Jiang, M. Xu, Angew. Chem. Int. Ed. 2004, 43, 25432546; d) J. J. Fleming, J. D. Bois, J. Am. Chem. Soc. 2006, 128, 39263927; e) K. Lauder, A. Toscani, N. Scalacci, D. Castagnolo, Chem Rev. 2017, 117, 14091-14200.

[2] a) M. Naoi, W. Maruyama, M. Shamoto-Nagai, H. Yi, Y. Akao, M. Tanaka, Mol. Neurobiol. 2005, 31, 81-93; b) J. J. Chen, D. M. Swope, K. 
Dashtipour, Clin.Ther. 2007, 29, 1825-1849; c) M. Baranyi, P. F Porceddu, F. Gölöncsér, S. Kulcsár, L. Otrokocsi, Á. Kittel, A. Pinna, L. Frau, P. B. Huleatt, M. L. Khoo, C. L. L. Chai, P. Dunkel, P. Mátyus, M. Morelli, B. Sperlágh, Mol. Neurodegener. 2016, 11, 6-26.

[3] a) R. Bloch, Chem. Rev. 1998, 98, 1407-1438; b) V. V. Kouznetsov, L. Y. V. Mendez, Synthesis. 2008, 491-506; c) G. Blay, A. Monleon, J. Pedro, Curr. Org. Chem. 2009, 13, 1498-1539.

[4] I. E. Kopka, Z. A. Fataftah, M. W. Rathke, J. Org. Chem. 1980, 45, 4616-4622.

[5] a) B. J. Wakefield, Academic Press, London, 1988, p 32; M. Umeno, A Suzuki, Handbook of Grignard Reagent, (Eds.: G. S. Silvermanand, P. E. Rakita), Dekker, New York, Vol. 64, p 645; b) R. Bloch, Chem. Rev. 1998, 98, 1407-1438; c) V. V. Kouznetsov, L. Y. V. Mendez, Synthesis 2008, 2008, 491-506.

[6] a) A. Dömling, W. Wang, K. Wang, Chem. Rev. 2012, 112, 3083-3135; b) M. Haji, Beilstein J. Org. Chem. 2016, 12, 1269-1301; c) J. P. Wan, L. Gana, Y. Liu, Org. Biomol. Chem. 2017, 15, 9031-9043.

[7] a) H. Naeimi, M. Moradian, Appl. Catal., A. 2013, 467, 400-406; b) M. Gholinejad, B. Karimi, A. Aminianfar, and M. Khorasani, ChemPlusChem 2015, 80, 1573-1579; c) M. Varyani, P. K. Khatri, S. L. Jain, Catal. Commun. 2016, 77, 113-117; d) J. Rosales, J. M. Garcia, E. Ávila, T. González, D. S. Coll, E. O. Mavárez, Inorg Chim. Acta. 2017, 467, 155-162; e) J. R. Cammarata, R. Rivera, F Fuentes, Y. Otero, E. O. Mavárez, A. Arce, J. M. Garcia Tetrahedron Lett. 2017, 58, 4078-4081; f) V. S. Kashid, M. S Balakrishna, Catal. Commun. 2018, 103, 78-82.

[8] S. Sakaguchi, T. Kubo, Y. Ishii, Angew. Chem. Int. Ed. 2001, 113, 2602-2604

[9] a) S. J. Borah, D. K. Das, Catal. Lett. 2016, 146, 656-665; b) N. Salam, S. K. Kundu, R. A. Molla, P. Mondal, A. Bhaumik, S. M. Islam, RSC Adv. 2014, 4, 47593.

[10] E. Ryaná Bonfield, Org. Biomol. Chem. 2007, 5, 435-437.

[11] R. K. Sharma, S. Sharma, G. Gaba, RSC Adv. 2014, 4, 49198-49211.

[12] M. Periasamy, P. O. Reddy, A. Edukondalu, M. Dalai, L. M. Alakonda, B. Udaykumar, Eur. J. Org. Chem. 2014, 2014, 6067-6076.

[13] M. Rahman, A. K. Bagdi, A. Majee, A. Hajra, Tetrahedron Lett. 2011, 52, 4437-4439.

[14] a) R. Dorel, A. M. Echavarren, Chem. Rev. 2015, 115, 9028-9072; b) K. Sugimoto, Y. Matsuya, Tetrahedron Lett. 2017, 58, 4420-4426; c) F. Gao, Y. Zhou, H. Liu, Curr. Org. Chem. 2017, 21, 1530-1566.

[15] C. Wei, C. J. Li, J. Am. Chem. Soc. 2003, 125, 9584-9585.

[16] a) V. K. Lo, Y. Y. Liu, M. K. Wong, C. M. Che, Org. Lett. 2006, 8 , 1529-1532; b) J. S. Yadav, B. V. S. Reddy, N. N. Yadav, M. K. Gupta, B. Sridhar, J. Org. Chem. 2008, 73, 6857-6859; c) V. K. Y. Lo, K. K. Y. Kung, M. K. Wong, C. M. Che, J. Organomet. Chem. 2009, 694, 583-591; d) B. T. Elie, C. Levine, I. UbarretxenaBelandia, A. Varela-Ramírez, R. J. Aguilera, R. Ovalle, M. Contel, Eur. J. Inorg. Chem. 2009, 2009, 3421-3430; (e) Q. Zhang, M. Cheng, X. Hu, B. G. Li, J. X. Ji, J. Am. Chem. Soc. 2010, 132 7256-7257; f) Y. Suzuki, S. Naoe, S. Oishi, N. Fujii, H. Ohno, Org Lett. 2012, 14, 326-329; g) J. Li, L. Liu, D. Ding, J. Sun, Y. Ji, J. Dong, Org. Lett. 2013, 15, 2884-2887; h) B. J. Borah, S. J. Borah, D. K. Dutta, J. Nanosci. Nanotechnol. 2013, 13, 5080-5087; i) V. Srinivas, M. Koketsu, Tetrahedron 2013, 69, 8025-8033; j) G. A Price, A. K. Brisdon, K. R. Flower, R. G. Pritchard, P. Quayle, Tetrahedron Lett. 2014, 55, 151-154; k) J. Li, H. Wang, J. Sun, Y. Yang, L. Liu, Org. Biomol. Chem. 2014, 12, 2523-2527; I) Q. Li, A. Das, S. Wang, Y. Chen, R. Jin, Chem. Commun. 2016, 52, 1429814301; m) E. Belmonte-Sánchez, M. J. Iglesias, H. el Hajjouji, L. Roces, S. García-Granda, P. Villuendas, F. López Ortiz, Organometllic 2017, 36, 1962-1973.

[17] a) M. L. Kantam, B. V. Prakash, C. R. V. Reddy, B. Sreedhar, Synlett 2005, 2005, 2329-2332; b) M. Kidwai, V. Bansal, A. Kumar, S. Mozumdar, Green Chem. 2007, 9, 742-745; c) X. Zhang, A. Corma, Angew. Chem. Int. Ed. 2008, 120, 4430-4433; d) K. K. R. Datta, B.
V. Reddy, K. Ariga, A. Vinu, Angew.Chem. Int. Ed. 2010, 49, 59615965; e) L. Abahmane, J. M. Köhler, G. A. Groß, Chem. Eur. J 2011, 17, 3005-3010; f) K. Layek, R. Chakravarti, M. L. Kantam, H. M. and A. Vinu, Green Chem., 2011, 13, 2878; g) G. Villaverde, A Corma, M. Iglesias, F. Sánchez, ACS Catal. 2012, 2, 399-406; h) L. F. Bobadilla, T. Blasco, J. A. Odriozola, Phys. Chem. Chem. Phys 2013, 15, 16927-16934; i) B. Karimi, M. Gholinejad, M. Khorasani Chem. Commun. 2012, 48, 8961-8963; j) L. Lili, Z. Xin, R. Shumin, Y. Ying, D. Xiaoping, G. Jinsen, H. Jing, RSC Adv. 2014, 4, 1309313107; k) S. K. Movahed, N. F. Lehi, M. Dabiri, RSC Adv. 2014, 4 42155-42158; I) B. J. Borah, S. J. Borah, D. K. Dutta, K. Saikia, Catal. Sci. Technol. 2014, 4, 4001-4009; m) A. Berrichi, R. Bachir, M. Benabdallah, N. Choukchou-Braham, Tetrahedron Lett. 2015 56, 1302-1306; n) M. Nasrollahzadeh, S. M. Sajadi, RSC Adv. 2015, 5, 46240-46246; o) S. Shabbir, Y. Lee, H. Rhee, J. Catal. 2015, 322, 104-108;

[18] a); Moghaddam, F. M.; Ayati, S. E.; Hosseini, S. H.; Pourjavadi, A RSC Adv. 2015, 5, 34502 b) L. Liu, X. Tai, N. Zhang, Q. Meng, C. Xin, React. Kinet. Mech. Catal. 2016, 119, 335-348; c) L. Liu, X Tai, G. Yu, H. Guo, Q. Meng, Chem. Res. Chin. Univ. 2016, 32 443-450; d) Y. Adachi, H. Kawasaki, T. Nagata, Y. Obora, Chem Lett. 2016, 45, 1457-1459; e) A. Feiz, A. Bazgir, Catal. Commun 2016, 73, 88-92; f) M. Gholinejad, F. Saadati, S. Shaybanizadeh, RSC Adv. 2016, 6, 4983-4991; g) M. Gholinejad, F. Hamed, C Najera, Synlett 2016, 27, 1193-1201; h) L. Liu, X. Tai, X. Zhou, C Xin, Y. Yan, Sci. Rep. 2017, 7, 12709-12718; i) X. B. Zhao, W. Ha K. Jiang, J. Chen, J. L. Yang, Y. P. Shi, Green Chem. 2017, 19, 1399-1406; j) L. Liu, X. Tai, X. Zhou, Materials 2017, 10, 99-112; k) N. Zohreh, S. H. Hosseini, M. Jahani, M. S. Xaba, R. Meijboom, J. Catal. 2017, 356, 255-268.; I) A. M. Munshi, M. Shi, S. P. Thomas, M. Saunders, M. A. Spackman, K. S. lyer, and N. M. Smith, Dalton Trans., 2017,46, 5133-5137

[19] G. Nagendrappa, App/ Clay Sci. 2011, 53, 106-138

[20] a) J. W. Hosterman, S. H. Patterson, Bentonite and Fuller's earth resources of the United States, Washington D.C. USA 1992; b) M. Moosavi, Iran. J. Public Health 2017, 46, 1176-1183; c) D. D. Eisenhour, R. K. Brown, Elements 2009, 5, 83-88.

[21] a) H. Firouzabadi, N. Iranpoor, A. Ghaderi, M. Gholinejad, S. Rahimi, S. Jokar, RSC Adv. 2014, 4, 27674-27682; b) B. Narayanamoorthy S. Balaji, Appl. Clay Sci. 2015, 104, 66-73; c) Q. F. Li, Z. Liu, L. Jin, P. Yang, Z. Wang, RSC Adv. 2017, 7, 44614-44618; d) Q. F. Li, L. Jin, L. Li, W. Ma, Z. Wang, J. Hao, J. Mater. Chem. C 2017, 5, 4670-4676.

[22]a) H. Zhang, X. Peng, Yuan, L. Asian J. Chem. 2012, 24, 3927-3928; b) W. Wang, H. Liu, G. Ding, P. Zhang, T. Wu, T. Jiang, B. Han, ChemCatChem. 2012, 4, 1836-1843; c) N. Hamzah, N. M. Nordin, A. H. A. Nadzri, Y. A. Nik, M. B. Kassim, M. A. Yarmo, Appl. Catal., A, General 2012, 419-420, 133-141; d) A. M. Sevim, R. Hojiyev, A Gul, M. S. Celik, Monatsh. Chem. 2012, 143, 385-400; e) W. Wang H. Liu, T. Wu, P. Zhang, G. Ding, S. Liang, T. Jiang, B. Han, J. Mol Catal. A: Chem. 2012, 355, 174-179; f) G. T. Wei, C. Y. Fan, L.Y. Zhang, R. C. Ye, T. Y. Wei, Z. F. Tong, Catal. Commun. 2012, 17, 184-188; g) R. J. Kalbasi, A. R. Massah, B. Daneshvarnejad, Appl. Clay Sci. 2012, 55, 1-9; h) O. B. Ayodele, B. H. Hameed, JIEC 2013, 19, 966-974; i) J. Z. Jin, N. B. Sun, Asian J. Chem. 2013, 25, 4441-4443; j) K. Muzakky, Wijaya, I. Prayogo, Int. J. Appl. Chem 2013, 9, 243-252; k) G. Ding, W. Wang, T. Jiang, B. Han, Green Chem. 2013, 15, 3396-3403; I) C. C. Yan, M. Li. Kai, Z. Yong. Hua, Toxicol. Environ. Chem. 2013, 95, 747-756; m) J. G. Qu, N. N. Li, B. J. Liu, J. X. He, Mater. Sci. Semicond. Process. 2013, 16, 99105; (n) R. Zhang, G. Guo, Y. Gao, L. Wang, N. Zhang, J. Cai, Mater. Lett. 2013, 113, 146-148; o) H. Faghihian, M. H. Mohammadi, Appl. Surf. Sci. 2013, 264, 492- 499; p) A. Juan, L. Meleroa, F. Bautista, J. Iglesias, G. Moralesa, R. Sánchez-Vazquez, Appl. Catal. B, 2014, 145, 197-204; q) G. E. Sataeva, N. M. 
Daurenbek, M. K. Myrzakhmet, J. Eng. Phys. Thermophys. 2014 87, 686-690; r) A. M. Al-Sabagh, F. Z. Yehia, G. h. Eshaq, A. E. El Metwally, Ind. Eng. Chem. Res. 2015, 54, 12474-12481; s) N. Belaidi, S. Bedrane, A. Choukchou-Braham, R. Bachir, Appl. Clay Sci. 2015, 107, 14-20; t) Y. Gao, Y. Wang, H. Zhang, Appl. Catal., B. 2015, 178, 29-36; u) R. Liu, X. Xia, X. Niu, G. Zhang, Y. Lu, R. Jiang, S. He, Appl. Clay Sci. 2015, 105-106, 71-77; v) X. Lu, F. Gub, Q. Liu, J. Gao, Y. Liu, H. Li, L. Jia, G. Xu, Z. Zhong, F. Su, Fuel Process. Technol. 2015, 135, 34-46; w) L. Rozic, B. Grbic, S. Petrovic, N. Radic, L. Damjanovic, Z. Vukovi, Mater. Chem. Phys. 2015, 167, 42-48; x) Y. Jiang, X. Li, Z. Qin, H. Ji, Chin. J. Chem. Eng. 2016, 24, 1195-1200; y) H. Gaffour, M. Mokhtari, Res. Chem. Intermed. 2016, 42, 6025-6038; z) L. Yuan, Pol. J. Environ. Stud. 2017, 26, 2355-2361; aa) V. M. Abbasov, H. C. Ibrahimov, G. S. Mukhtarova, M. I. Rustamov, E. Abdullayev, Energy Fuels 2017, 31 , 5840-5843; bb) Y. Jiang, T. Huang, Y. Xu, X. Li, Z. Qin, H. Ji, Chem. Eng. Technol. 2018, 41, 175-181.

[23] a) M. Shahabinejad, G. Ghasemi, M. V. Martínez-Huerta, M. Ghiaci, J. Mol. Catal. A: Chem. 2015, 406, 118-126; b) R. J. Maya, J. John, R. L. Varma, Chem. Commun. 2016, 52, 10625-10628; c) P. K. Rastogi, D. K. Yadav, S. Pandey, V. Ganesan, P. K. Sonkar, R. J.
Gupta, Chem. Sci. 2016, 128, 349-356; d) R. J. Maya, S. Poulose J. John, R. Luxmi Varma, Adv. Synth. Catal. 2017, 359, 1177-1184.

[24] L. Zhirong, M. A. Uddin, S. Zhanxue, Spectrochim. Acta A. 2011, 79 1013-1016.

[25] Y. Zhang, L. Chen, J. J. Zhao, H. B. Chen, M. X. He, Y. P. Ni, J. Q. Zhai, X. L. Wang, Y. Z. Wang, Polym. Chem. 2014, 5, 1982-1991.

[26] Q. Liu, J. Li, Z. Zhou, J. Xie, J. Y. Lee, Sci Rep. 2016, 6, 1959319603.

[27] a) Y. Zhang, X. He, J. Ouyang, H. Yang, Sci. Rep. 2013, 3, 29482954; b) V. Dalmoro, J. H. Z. dos Santos, I. M. Baibich, I. S. Butler, E. Armelin, C. Alemán, D. S. Azambuja, Prog. Org. Coat. 2015, 80, 49-58.

[28] a) E. Mazzotta, S. Rella, A. Turco, C. Malitesta, RSC Adv. 2015, 5, 83164-83186; b) Y. Zhang, Z. Xie, Z. Wang, X. Feng, Y. Wang, A. Wu, Dalton Trans. 2016, 45, 12653-12660. 


\section{Layout 2:}

\section{FULL PAPER}

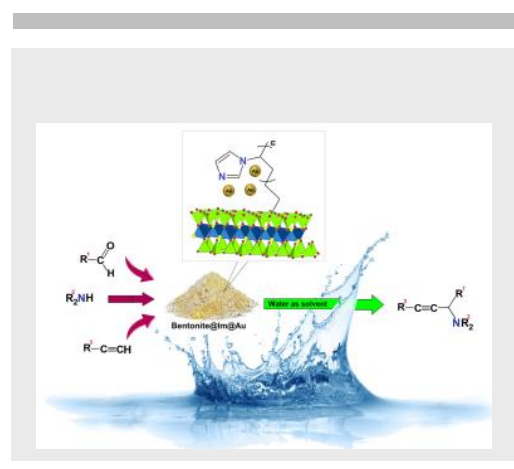

Mohammad Gholinejad, ${ }^{*[a, b]}$ Reza

Bonyasi ${ }^{[c]}$ Carmen Najera, ${ }^{* d]}$ Fariba Saadati, ${ }^{[c]}$ Maedeh Bahrami, ${ }^{[a]}$ Neda Dasvarz ${ }^{[a]}$

Page No. - Page No.

Gold Nanoparticles Supported on Imidazole Modified Bentonite:

Environmentally Benign Heterogeneous Catalyst for A3 Synthesis of Propargylamines in Water 